December 2019

\title{
Is Bioethics Relevant?
}

Heather G. Kuruvilla

Follow this and additional works at: https://digitalcommons.cedarville.edu/

bioethics_in_faith_and_practice

Part of the Bioethics and Medical Ethics Commons

DigitalCommons@Cedarville provides a publication platform for fully open access journals, which means that all articles are available on the Internet to all users immediately upon publication. However, the opinions and sentiments expressed by the authors of articles published in our journals do not necessarily indicate the endorsement or reflect the views of DigitalCommons@Cedarville, the Centennial Library, or Cedarville University and its employees. The authors are solely responsible for the content of their work. Please address questions to dc@cedarville.edu.

\section{Recommended Citation}

Kuruvilla, Heather G. (2019) "Is Bioethics Relevant?," Bioethics in Faith and Practice: Vol. 4 : No. 1 , Article 1.

DOI: 10.15385/jbfp.2019.4.1.1

Available at: https://digitalcommons.cedarville.edu/bioethics_in_faith_and_practice/vol4/iss1/1 


\title{
Is Bioethics Relevant?
}

\begin{abstract}
We live in a broken, unjust, and often dangerous world. Technology promises hope; hope for new cures, broader access to information, and a better quality of life for humankind. Technologies such as gene editing and artificial intelligence continue to progress at a pace we have never seen before, running far ahead of the ethical discussions surrounding their stewardship. In a technology-driven culture like ours, one might be tempted to ask whether the ethical discussion is still relevant.
\end{abstract}

\section{Keywords}

CRISPR, gene editing, abortion, pro-life

Creative Commons License

\section{(c) (i) $\Theta \Theta$}

This work is licensed under a Creative Commons Attribution-Noncommercial-No Derivative Works 4.0 License. 


\section{From the Managing Editor \\ Is Bioethics Relevant? \\ Heather G. Kuruvilla, Ph.D. \\ Cedarville University}

We live in a broken, unjust, and often dangerous world. Technology promises hope; hope for new cures, broader access to information, and a better quality of life for humankind. Technologies such as gene editing and artificial intelligence continue to progress at a pace we have never seen before, running far ahead of the ethical discussions surrounding their stewardship.

In a technology-driven culture like ours, one might be tempted to ask whether the ethical discussion is still relevant. Take the example of the young girls who were genetically modified as embryos, using CRISPR, in China last year. The embryos were edited to modify a specific protein, CCR5, in order to make the girls HIV-resistant. New data are emerging that indicate not all of the cells in the embryo were edited, and that the change in the CCR5 protein may not have given the girls any HIV resistance. ${ }^{1}$ The risk of off-target mutations remains, and because these mutations may exist in the girls' germlines, they can now be passed to future generations.

Dimitri Perrin and Gaetan Burgio, when discussing this case, note that "embryo editing is only ethically justifiable in cases where the benefits clearly outweigh the risks." " However, "we are just not ready for human embryo editing. Our techniques are not mature enough, and no case has been made for a widespread need..."3 The authors stress the need for governance and a possible moratorium on embryo editing until techniques mature, noting the lack of scientific and ethical consensus at present. Bioethics must inform this discussion.

Meanwhile, in the political arena, the debate over when human personhood begins continues to take center stage as an increasing number of states allow abortions all the way up until the time of birth. Presidential candidate Pete Buttigieg, defending abortion rights, noted, “... there's a lot of parts of the Bible that talk about how life begins with breath, and so even that is something that we can interpret differently..."4, implying that personhood begins with birth. As author Ross Douthat has noted, this position is not scientifically defensible, since the primary biological difference between a nearly-born fetus and a newborn is their position (inside vs. outside the uterus) and the fact that the newborn is using

\footnotetext{
${ }^{1}$ Perrin, Dmitri, and Burgio, Gaetan. New details about the infamous "CRISPR babies" have just been revealed. Science Alert: 9 December 2019.

${ }^{2}$ Ibid

${ }^{3}$ Ibid

${ }^{4}$ Douthat, Ross. The abortion mysticism of Pete Buttigieg. The New York Times: 17 September 2019

Bioethics in Faith and Practice vol. 4 no. 1, pp. 1-3. ISSN 2374-1597 (C 2019, Heather Kuruvilla, licensed under CC BY-NC-ND (http://creativecommons.org/licenses/by-nc-nd/4.0/ )
} 
his/her lungs to breathe, rather than obtaining oxygen through the placenta. ${ }^{5}$ These small physiological differences should not determine the metaphysical basis for personhood.

Bernie Sanders has taken this rhetoric a step further, arguing that the Mexico City agreement, which bans the use of US foreign aid for abortion services, should be overturned in order to provide another weapon against climate change. ${ }^{6}$ Stewardship of creation was one of the first tasks given to humankind by God; however, He also created human persons in His image. Navigating the tension between valuing human persons as bearers of the Imago Dei and wisely stewarding the resources God has given us is one that requires wisdom, logic, and bioethical principles.

Is it too late for bioethics to make a difference in this technological age? Certainly not! Scientific facts alone, while important for informing ethical decisions, cannot tell us how technology should be used. Principles such as beneficence, nonmaleficence, and justice loom large as we consider gene editing, artificial intelligence, access to abortion, and many other issues which have implications for human personhood. This is not the time for people of faith to sit on the sidelines and allow pragmatism alone to dictate how we, as a society, determine what is good for all human persons, including those who cannot speak for themselves. The time for bioethics is now.

${ }^{5} \mathrm{lbid}$

${ }^{6}$ Blake, Aaron. On Bernie Sanders, abortion, and 'population control'. The Washington Post: 5 September 2019 


\section{Bibliography}

1. Blake, Aaron. On Bernie Sanders, abortion, and 'population control'. The Washington Post: 5 September 2019

2. Douthat, Ross. The abortion mysticism of Pete Buttigieg. The New York Times: 17 September 2019

3. Perrin, Dmitri, and Burgio, Gaetan. New details about the infamous "CRISPR babies" have just been revealed. Science Alert: 9 December 2019. 